\title{
Ants (Hymenoptera: Formicidae) of Niue, Polynesia ${ }^{1}$
}

\author{
Fames K. Wetterer ${ }^{2}$
}

\begin{abstract}
Niue is a single isolated island in Polynesia. Based on reexamination of specimens from an earlier study and unpublished specimen data, I removed three erroneous records from the list of known ants from Niue (Paratrechina flavipes, Pheidole mus, and Tetramorium bicarinatum), corrected one name (Monomorium liliuokalanii instead of Monomorium monomorium), and added one new species record (Vollenhovia samoensis). Of the 33 ant species I report from Niue, 18 are Indo-Pacific natives and 15 are exotics. The ant fauna of Niue is almost entirely a subset of the fauna of neighboring Tonga and Samoa. Of the ant species native to the Indo-Pacific region found in Niue, only one was not also known from both Tonga and Samoa. Most or all of the other 17 species seem likely to be native to Niue (i.e., predating human arrival). This is particularly apparent for a local endemic species, $V$. samoensis, which was once considered to be a Samoan endemic but is now also known from Tonga and Niue.
\end{abstract}

In Oceania, the ancestors of most species came from the west, carried by prevailing currents from Australia, New Guinea, and Southeast Asia (Wilson 1961, Carlquist 1965). Most-distant islands received fewer colonists, and from west to east across Oceania there is a steady decline in the number of families, genera, and species found on islands (Carlquist 1965). For example, western Oceania has a rich native ant fauna with many endemic species (Wilson 1961, Wilson and Taylor 1967). In contrast, Wilson and Taylor (1967:5) concluded, "prior to the coming of man, few if any native [ant] species ranged east of New Zealand, Rotuma, Samoa, and Tonga." Here, I consider the ants of Niue $\left(19^{\circ} \mathrm{S}, 170^{\circ} \mathrm{W}\right)$, a single isolated island in west-central Polynesia located $480 \mathrm{~km}$ east of Tonga and $560 \mathrm{~km}$ south-southeast of Samoa, just beyond the hypothesized general limit of native ants in Oceania.

${ }^{1}$ Financial support was provided by Florida Atlantic University. Manuscript accepted 3 August 2005.

${ }^{2}$ Wilkes Honors College, Florida Atlantic University, 5353 Parkside Drive, Jupiter, Florida 33458 (phone: 561799-8648; fax: 561-799-8602; e-mail: wetterer@fau.edu).

Pacific Science (2006), vol. 60, no. 3:413-416

(C) 2006 by University of Hawai'i Press

All rights reserved
Taylor (1967:1093) published the first ant records from Niue, dividing 19 reported species into two groups, nine that ranged "from the Indo-Australian area into Polynesia" and 10 that were "certainly distributed by recent human commerce" to Niue. Despite placing almost half of the species known from Niue in the first category, Taylor (1967:1093) concluded that the ants of Niue originated "largely, if not entirely, from propagules introduced by man." Collingwood and van Harten (2001) recently reported a muchexpanded list of 35 ant species from Niue, based on published records and on new specimens collected by van Harten. In this note I correct a few errors in Collingwood and van Harten's (2001) paper, provide some additional data concerning the ants of Niue, and evaluate which ant species appear to be native to Niue (i.e., predating human arrival) and which are exotics.

When considering past ant records from Niue, Collingwood and van Harten (2001) included information from Taylor (1967) and Dlussky (1994). The records listed from Dlussky (1994), however, were not for specimens from Niue, but instead from Niuafo'ou, an island in northernmost Tonga. This mistake added one erroneous species record not otherwise known from Niue, Tetramorium bicarinatum.

Among the ant specimens collected by van 
Harten, Collingwood identified 28 species, including Monomorium monomorium, which is Bolton's (1987) replacement name for Monomorium minutum. Bolton (1987), however, examined specimens from Oceania that had been assigned to $M$. minutum and found that they were a separate, native Pacific species, Monomorium liliuokalanii. The same is no doubt true for the Niue samples.

Collingwood and van Harten's (2001) new records for Niue represented large extensions of the known ranges for five ant species. There were no previous records of Paratrechina flavipes and Pheidole mus from anywhere in Oceania. Strumigenys lewisi and Tetramorium smithi were previously reported in Oceania only from Hawai' $i$ and the Caroline Islands, respectively. And finally, the five $\mathrm{Am}$ blyopone species known from Oceania are all from sites distant from Niue: the Solomon Islands, New Caledonia, Vanuatu, New Zealand, the Mariana Islands, and Hawai'i. I sought to verify identification of these anomalous records. I also looked for any previously unpublished ant records from Niue.

\section{MATERIALS AND METHODS}

Cedric Collingwood provided specimens collected by van Harten in Niue that were identified as Paratrechina flavipes (one worker and one queen), Pheidole mus (one minor worker), Strumigenys lewisi (three workers), and Tetramorium smithi (two workers). Collingwood did not send the single damaged (headless) Amblyopone specimen.

I also considered additional unpublished ant records from Niue: specimens in the American Museum of Natural History in New York (АмNH) and the New Zealand Arthropod Collection (NZAC) and new specimens collected by Wilco Liebregts, now deposited at Harvard University's Museum of Comparative Zoology (MCZ).

\section{RESULTS}

James Trager reexamined van Harten's specimens identified as $P$. flavipes, a temperate Asian species that has also been introduced to the northeastern United States (Trager
1984; J. Trager, pers. comm.). Trager concluded that the Niue specimens were not $P$. flavipes but instead Paratrechina vaga, a species already reported from Niue.

Stefan Cover reexamined van Harten's specimens identified as $P$. mus, S. lewisi, and T. smithi. Cover confirmed that the surprising identifications of S. lewisi and T. smithi were correct. Cover compared the Pheidole specimen with $P$. mus syntypes from India and concluded that they did not match. Cover, however, could not place a species name on the Pheidole specimen.

The New Zealand Arthropod Collection (NZAC) had ant specimens from Niue representing 16 species (Tables 1,2 ), including a species not previously recorded from Niue: one specimen of Vollenhovia samoensis determined by Robert W. Taylor labeled: "Niue Island, Alofi South, 14 September 1975, G. Kuschel, sifted litter above coastal cliffs. Litter 72/167."

The American Museum of Natural History in New York has 50 pinned ant specimens that Noel L. H. Krauss collected in Alofi, Niue, in January 1978. Cover identified the specimens as belonging to 10 species (Tables 1,2).

Wilco Liebregts collected ants in Alofi on 26-27 May 1997 and in Vaipapahi on 27 May 1997; Cover identified all as Pheidole megacephala.

\section{DISCUSSION}

Collingwood and van Harten (2001) listed 35 ant species from Niue. I removed three erroneous records from that list (Paratrechina flavipes, Pheidole mus, and Tetramorium bicarinatum), corrected one name (Monomorium monomorium to Monomorium liliuokalanii), and added one new record (Vollenhovia samoensis). Of the 33 ant species known from Niue, 18 are Indo-Pacific natives and 15 are exotics (Tables 1, 2 [see analyses in Wetterer 2002, Seifert 2003, Wetterer and Vargo 2003]). The ant fauna of Niue is almost entirely a subset of species known from neighboring Tonga (53 species [Wetterer 2002]) and Samoa (68 species [Wetterer and Vargo 2003]). Of the 18 ant species considered native to the 
TABLE 1

Native Indo-Pacific Ant Species in Niue

\begin{tabular}{|c|c|c|c|c|c|}
\hline \multirow[b]{2}{*}{ Species } & \multirow{2}{*}{$\begin{array}{c}\text { Niue } \\
\text { Records }{ }^{a}\end{array}$} & \multicolumn{3}{|c|}{ Known Pacific Range ${ }^{b}$} & \multirow[b]{2}{*}{ Origin $^{c}$} \\
\hline & & PMCATG & SNVF & ZWSTNCFPEXOLH & \\
\hline Amblyopone sp. & $---\mathrm{V}$ & $-M----$ & $\mathrm{SNV}_{-}$ & $\mathrm{Z}---\mathbf{N}-------\mathrm{H}$ & ? \\
\hline Camponotus chloroticus Emery & tnkv & -MCAT- & SNVF & -WSTN-----O-- & $\mathrm{PO}$ \\
\hline Cardiocondyla nuda (Mayr) & tnkv & ------ & $\mathrm{S}-\mathrm{VF}$ & -WSTN -------- & ** \\
\hline Monomorium liliuokalanii Forel & $--\mathrm{kv}$ & $-\mathrm{MC}---$ & ---- & -- STNCFP $----\mathrm{H}$ & ** \\
\hline Monomorium australicum Forel & $---\mathrm{v}$ & $--\mathrm{C}---$ & $\mathrm{S}-\mathrm{VF}$ & $--\mathrm{STNCF}---\ldots--$ & ** \\
\hline Odontomachus simillimus Smith & $---\mathrm{v}$ & PMCA-- & SNVF & $-\mathrm{WSTN}-\mathrm{F}---\mathrm{O}--$ & $\mathrm{PO}$ \\
\hline Pheidole oceanica Mayr & tnkv & -MCAT- & SNVF & -WSTNCF---OL- & NG \\
\hline Pheidole sexspinosa Mayr & $\mathrm{tn}--$ & --CAT- & $\mathrm{S}-\mathrm{V}-$ & -WSTN-F------ & NG \\
\hline Pheidole umbonata Mayr & $\mathrm{t}-\mathrm{k}-$ & PMC --- & SNVF & -WSTNCF------ & NG \\
\hline Ponera tenuis (Emery) & $---\mathrm{v}$ & $-\mathrm{MC}---$ & ---- & $--\mathrm{STN}--------$ & NG \\
\hline Rogeria stigmatica Emery & $---\mathrm{v}$ & $--\mathrm{C}---$ & SNVF & -WSTNCF------ & ** \\
\hline Strumigenys godeffroyi Mayr & $---\mathrm{v}$ & $-\mathrm{MCA}--$ & SNVF & - WSTNCF $-----\mathrm{H}$ & $\mathrm{PO}$ \\
\hline Tapinoma minutum Mayr & tnk- & $-\mathrm{MC}---$ & $\mathrm{S}--\mathrm{F}$ & -WSTN-F------ & $\mathrm{PO}$ \\
\hline Technomyrmex albipes (Smith) & $t--v$ & PMC-T- & SNVF & ZWSTNCFP--O-H & $\mathrm{PO}$ \\
\hline Tetramorium insolens (Smith) & th- - & $--\mathrm{C}---$ & SNVF & - WSTN-------H & ** \\
\hline Tetramorium pacificum Mayr & $\operatorname{tn}-\mathrm{v}$ & $--\mathrm{C}---$ & SNVF & -WSTNCFP----- & $\mathrm{PO}$ \\
\hline Tetramorium tonganum Mayr & $\mathrm{t}---$ & $-\mathrm{MC}---$ & $\mathrm{S}-\mathrm{VF}$ & -WSTNCF----LH & $\mathrm{RE}$ \\
\hline Vollenhovia samoensis Mayr* & $-\mathrm{n}--$ & ------ & ---- & $--\mathrm{STN}--------$ & $\mathrm{ES}$ \\
\hline
\end{tabular}

${ }^{a}$ t, Taylor (1967); n, NZAC; k, Krauss; v, van Harten.

${ }^{b}$ Known Pacific range (unpubl. compilation): Micronesia (PMCATG: P, Palau; M, Mariana Is.; C, Caroline Is.; A, Marshall Is.; T, Tuvalu; G, Gilbert Is.); Melanesia (SNVF: S, Solomon Is.; N, New Caledonia; V, Vanuatu; F, Fiji); Polynesia (ZWSTNCFPEXOLH: Z, New Zealand; W, Wallis and Futuna; S, Samoa; T, Tonga; N, Niue; C, Cook Is.; F, French Polynesia; P, Pitcairn; E, Easter; X, Phoenix Is.; O, Tokelau Is.; L, Line Is.; H, Hawai'i).

${ }^{c}$ Status in Dlussky (1994): ES, Samoa endemic; RE, regional endemic; NG, New Guinean origin; PO, pantropical of Asian origin. ${ }^{*}$, New record; ${ }^{* *}$, taxonomic status changed since Dlussky (1994).

TABLE 2

Exotic Ant Species in Niue

\begin{tabular}{|c|c|c|c|c|c|}
\hline \multirow[b]{2}{*}{ Species } & \multirow{2}{*}{$\begin{array}{l}\text { Niue } \\
\text { Records }\end{array}$} & \multicolumn{3}{|c|}{ Known Pacific Range } & \multirow[b]{2}{*}{ Origin } \\
\hline & & PMCATG & SNVF & ZWSTNCFPEXOLH & \\
\hline Anoplolepis gracilipes (Smith) & $\mathrm{t}--\mathrm{v}$ & PMCAT- & SNVF & -WSTNCF---OLH & $\mathrm{PA}$ \\
\hline Cardiocondyla emeryi Forel & tnkv & $-M----$ & $--\mathrm{VF}$ & -WSTNCFP----H & $\mathrm{PA}$ \\
\hline Hypoponera punctatissima (Roger) & $---\mathrm{v}$ & $-\mathrm{MC}---$ & SNVF & ZWSTN-F-----H & PA \\
\hline Monomorium destructor (Jerdon) & $---\mathrm{v}$ & $-\mathrm{M}-\mathrm{A}-\mathrm{G}$ & ---- & $--\mathrm{S}-\mathrm{NCF}-----\mathrm{H}$ & PA \\
\hline Monomorium floricola (Jerdon) & tnkv & PMCA-- & SNVF & ZWSTNCFP_-OLH & $\mathrm{PO}$ \\
\hline Paratrechina bourbonica Forel & $--\mathrm{kv}$ & -MCA-- & SN-F & -WSTNCFPEXOLH & $\mathrm{PO}$ \\
\hline Paratrechina longicornis (Latr.) & $\mathrm{tn}--$ & -MCAT- & SNVF & -WSTNCFPEXOLH & PO \\
\hline Paratrechina vaga (Nylander) & $\mathrm{tn}-\mathrm{v}$ & $-\mathrm{MC}-\mathrm{T}-$ & SNVF & ZWSTNCFP-XOLH & $\mathrm{PO}$ \\
\hline Pheidole megacephala (Fabr.) & tnkv & $-\mathrm{MCA}--$ & SNVF & ZWSTNCF---OLH & $\mathrm{PA}$ \\
\hline Plagiolepis alluaudi Emery & $\mathrm{tn}-\mathrm{v}$ & ------ & $-\mathrm{NVF}$ & Z--TNCF-E---H & PA \\
\hline Strumigenys lewisi Cameron & $---\mathrm{v}$ & ------ & ---- & $----\mathbf{N}-------\mathrm{H}$ & o \\
\hline Strumigenys rogeri Emery & $---\mathrm{v}$ & $-\mathrm{MC}---$ & SNVF & - WSTN-F- $----\mathrm{H}$ & PA \\
\hline Tapinoma melanocephalum (Fabr.) & $\mathrm{tn}-\mathrm{v}$ & PMCA-- & SNVF & ZWSTNCFP-XO-H & $\mathrm{PO}$ \\
\hline Tetramorium simillimum (Smith) & $\mathrm{tn}-\mathrm{v}$ & $-\mathrm{MCA}--$ & SNVF & -WSTNCFPEXOLH & $\mathrm{PA}$ \\
\hline Tetramorium smithi Mayr & $---\mathrm{v}$ & $--\mathrm{C}---$ & ---- & $----\mathbf{N}--------$ & 0 \\
\hline
\end{tabular}

${ }^{a}$ PA, pantropical of African origin; o, not included in Dlussky (1994). Other symbols as in Table 1. 
Indo-Pacific region found in Niue, only one, Amblyopone sp., is not also known from both Tonga and Samoa. If the other 17 species are native to Samoa and Tonga (Wetterer 2002, Wetterer and Vargo 2003), then it seems likely that most or all predate human arrival in Niue as well. This seems particularly likely for Vollenhovia samoensis, a local endemic species that was once considered to be a Samoan endemic but is now also known from Tonga (Wetterer 2002) and Niue (this paper).

Many of van Harten's new records are inconspicuous species that are often overlooked by casual collectors (e.g., $H$. punctatissima, $P$. tenuis, S. godeffroyi, S. lewisi, and S. rogeri). There are almost certainly additional ant species in Niue, perhaps even endemic species, that have not yet been found. Additional ant collecting in Niue is certainly warranted.

\section{ACKNOWLEDGMENTS}

I thank A. Wetterer and M. Wetterer for comments on the manuscript; C. Collingwood and $W$. Liebregts for providing specimens; S. Cover, J. Trager, and D. Ward for identifying ants; and J. Berry for information on specimens at NZAC.

\section{Literature Cited}

Bolton, B. 1987. A review of the Solenopsis genus-group and revision of Afrotropical Monomorium Mayr (Hymenoptera: Formicidae). Bull. Br. Mus. Nat. Hist. Entomol. 54:263-452.

Carlquist, S. 1965. Island life: A natural history of the islands of the world. Natural History Press, New York.
Collingwood, C. A., and A. van Harten. 2001. The ants (Hym., Formicidae) of Niue, south west Pacific. Entomol. Mon. Mag. 137:139-144.

Dlussky, G. M. 1994. Zoogeography of southwestern Oceania [in Russian]. Pages 48-93 in Y. G. Puzatchenko, S. I. Golovatch, G. M. Dlussky, K. N. Diakonov, A. A. Zakharov, and G. A. Korganova, eds. Animal population of the islands of southwestern Oceania (ecogeographic studies). Nauka Publishers, Moscow.

Seifert, B. 2003. The ant genus Cardiocondyla (Insecta: Hymenoptera: Formicidae): A taxonomic revision of the $C$. elegans, $C$. bulgarica, C. batesii, C. nuda, C. shuckardi, C. stambuloffi, C. wroughtonii, C. emeryi, and $C$. minutior species groups. Ann. Naturhist. Mus. Wien Ser. B Bot. Zool. 104:203-338.

Taylor, R. W. 1967. Entomological survey of the Cook Islands and Niue. 1 . Hymenoptera-Formicidae. N. Z. J. Sci. 10:1092-1095.

Trager, J. C. 1984. A revision of the genus Paratrechina (Hymenoptera: Formicidae) of the continental United States. Sociobiology 9:49-162.

Wetterer, J. K. 2002. Ants of Tonga. Pac. Sci. 56:125-135.

Wetterer, J. K., and D. L. Vargo. 2003. Ants (Hymenoptera: Formicidae) of Samoa. Pac. Sci. 57:409-419.

Wilson, E. O. 1961. The nature of the taxon cycle in the Melanesian ant fauna. Am. Nat. 95:169-193.

Wilson, E. O., and R. W. Taylor. 1967. Ants of Polynesia. Pac. Insects Monogr. 14:1109. 